Fiona J.McDonald, UNIVERSITY OF OTAGO, fiona.mcdonald@otago.ac.nz

\title{
Changes in Approaches to Learning Over Three Years of University Undergraduate Study
}

\begin{abstract}
This study aimed to evaluate and compare approaches to learning by a longitudinal cohort of undergraduate students as they progressed from their first to third years of study in anatomy and physiology. The Approaches and Study Skills Inventory for Students (ASSIST) was completed at the beginning and end of their first year of university study, and in their final semester. At first year, a surface learning approach predominated; however, at third year, students showed a significant increase in their use of deep and strategic learning approaches compared to first year, although surface learning approaches were retained. The extent to which third-year students took both strategic and deep approaches to learning was positively correlated with their performance on assessment. As students progress through a three-year science degree, they develop deeper and more strategic learning approaches, and assessment and teaching styles probably promote these approaches to learning.
\end{abstract}

\section{KEYWORDS}

learning inventory, ASSIST, physiology, anatomy, longitudinal study

\section{INTRODUCTION}

This study aimed to evaluate and compare approaches to learning by a longitudinal cohort of undergraduate students as they progressed from their first through third years of university science study. Tertiary education is believed to promote independent and deeper approaches to learning, and indeed this outcome is often part of the institutional requirements of a university. A prevailing view in the literature is that deep learning approaches promote strong long-lasting learning outcomes, whereas surface approaches promote weaker learning outcomes (e.g., Marton \& Säljö, 1997; Prosser \& Trigwell, 1999; Trigwell, Prosser, \& Waterhouse, 1999; Entwistle \& Peterson, 2004). Marton and Säljös' (1976) development of the concept of deep and surface approaches to learning is an underlying theme in the literature on student learning. Students who rely on surface approaches are likely to memorise information without context, whereas students adopting deep approaches use a relational way of thinking, integrating information, and looking to the bigger picture to understand the material (Biggs 1987; Entwistle \& Ramsden, 1983; Marton \& Säljö, 1997). A strategic approach (Entwistle, Hanley, \& Hounsell, 1979) takes into account contextual pressures such as assessments, where students choose to change their approaches depending on their environment. Entwistle and Ramsden (1983) suggested that learning within some disciplines, such as science, may require an emphasis on detail and procedure, and that there may even be a preliminary stage of rote learning that is difficult to distinguish from a 
surface approach. Thus some researchers (e.g., Marton, Dall'Alba, \& Tse, 1993) have distinguished between meaningless (rote) memorising and meaningful (deep) memorising.

Multiple studies have investigated the links between approaches to learning and learning outcomes, but the results have been mixed and sometimes conflicting. Some studies report a positive effect of learning outcomes with an increase in a deep approach to learning (e.g., Entwistle, Tait, \& McCune, 2000; Diseth \& Martinsen, 2003; Diseth, 2007). However, Diseth and Martinsen (2003) reported that deep approaches did not predict achievement in a cohort of undergraduate psychology students, and our own study of first-year science students showed that a surface approach correlated with achievement (Walker, Spronken-Smith, Bond, McDonald, Reynolds, \& Martin, 2010). As Entwistle (2000) stated, “A deep approach to studying is generally related to high levels of academic achievement, but only where the assessment procedures emphasise and reward personal understanding" (p.4). Thus contextual factors become important in interpreting studies reported in the literature (Baeten, Kyndt, Struyven, \& Dochy, 2010; Dinsmore \& Alexander, 2012).

Dinsmore and Alexander (2012) critically reviewed 221 articles that studied deep and surface processing and suggested that variability in 1) definition of a theoretical framework for a study, 2) type of measure, 3) validity evidence, and 4) context (e.g., the students were asked to answer questions based on their learning approaches in a particular course) contributed to inconsistent reported relationships between processing and learning outcomes. Baeten, Kyndt, Struyven and Dochy (2010) categorised the contextual and student factors that "encourage or discourage the adoption of deep approaches to learning in a student-centred learning environment" (p. 245) and reported that assessment, feedback, teachers' approaches and interactivity with the class, and study discipline influenced student learning approaches. Further, perceived contextual factors such as supportiveness, relevance to intended profession, workload, and teaching style were also important. Several studies have focused on how teachers' approaches to teaching may also influence students' approaches to learning (e.g. Gibbs \& Coffey, 2004; Kane, Sandretto, \& Heath, 2002; Kember \& Kwon, 2000; Postareff, Lindblom-Yla "nne, \& Nevgi, 2007; Samuelowicz \& Bain, 1992; Trigwell et al, 1999). Student factors, particularly age, personality, previous experience, and initial learning approach were found to influence student approaches to learning. Evidence for gender or intellectual ability being important was difficult to interpret as opposite results or only a few studies were found.

\section{Learning inventories}

Self-report student learning inventory questionnaires were used in 50\% of the articles analysed by Dinsmore and Alexander (2012) to inform their review of factors that influence learning outcomes. As a measure, self-reports are easy to administer and produce a large amount of information from many participants; however, limitations include the accuracy of participants scoring their own learning strategies. Other measuring tools such as carrying out a task, interviews, or analysis of diary entries may give more insight into cognitive ability (Dinsmore, Alexander, \& Loughlin, 2008).

Student learning inventories have several origins. First, educational research traditions led to the development of the Approaches to Studying Inventory (ASI) (Entwistle \& Ramsden,1983) that was reformulated as the Approaches and Study Skills Inventory for Students (ASSIST) (Tait, Entwistle, \& McCune, 1998) and the Study Processes Questionnaire (SPQ) (Biggs, 1987). Second, stemming from the psychological tradition of understanding metacognition was the development of the Inventory of Learning Processes (ILP) (Schmeck, Ribich, \& Ramanaiah, 1977), and a revised measure (ILP-R) that drew on aspects of the ASI and SPQ (Schmeck, Geisler-Brenstein, \& Cercy, 1991). Finally, the Learning and Study Strategies Inventory (LASSI) grew out of an analysis of study skill training courses 
(Weinstein, 1982). Entwistle and McCune (2004) indicate that there is much overlap in these major self-report inventories, particularly in their dissociation of deep versus surface processing, or approaches to learning. Some self-report surveys such as the Inventory of Learning Styles (ILS) (Vermut, 1996) and Motivated Strategies for Learning Questionnaire (MSLQ) (Pintrich, 1991) incorporated elements of self-regulation and measured how students monitor, reflect, and regulate their learning. The ILS overlaps with the ASI and SPQ in its use of 'meaning directed' and 'reproducing directed' that relate to deep and surface learning approaches respectively. Thus, although multiple self-report questionnaires are used and reported, they all share an analysis of a deep/meaningful learning process compared to a memorisation/surface learning process.

In our studies we have used the Approaches and Study Skills Inventory for Students (ASSIST) (Tait et al., 1998) that stems from the Approaches to Studying Inventory (ASI) (Entwistle \& Ramsden, 1983). This inventory is derived from a large amount of both qualitative and quantitative research (Entwistle, 1997) and has been used in multiple studies to evaluate different aspects of students' learning (e.g. Byrne, Flood, \& Willis, 2002; Diseth, 2007; Diseth \& Martinsen, 2003; Gibbs, 1999; Greasley \& Bennet, 2004; Maguire, Evans, \& Dyas, 2001; Reid, Duvall, \& Evans, 2007; Speth, Lee \& Hain, 2006; Webster, 2002). Ertl and Wright (2008) reviewed the literature on learning approaches in the UK and questioned the reliability of learning style questionnaires, as well as the value they were adding to enhancing student experience in higher education, but they also stated that "Better studies in this genre have a planned longitudinal element in the research design...” (p. 200). It should be emphasised here that our focus with the ASSIST questionnaire was on determining the students' approaches to organising information for understanding and retention, rather than evaluating what mode of instruction (e.g., visual versus auditory) was more effective for them. Interestingly, Pashler, McDaniel, Rohrer \& Bjork, (2008) surveyed the literature to find evidence linking student preferences for learning with teaching environment suited to their preferences. These authors found very little evidence for a positive effect of mode of instruction specific for student preference, and found in fact that a number of studies reported negative outcomes for the learning-styles hypothesis. But the authors also noted that types of instruction should alter to suit the teaching of a certain subject, and that students will likely benefit from material presented in a certain way and this may differ between individual students.

\section{Longitudinal studies measuring changes in approaches to learning}

A limited number of longitudinal studies on student learning in tertiary institutions have been reported, with the results being mixed. Watkins and Hattie (1985) used the ASI and reported that over three years a deeper approach to learning declined in Australian students. A study from first and third year students in Hong Kong found that deep approach use declined in third year students, but that older students tended to use deep approaches more (Gow \& Kember 1990). Zeegers (2001) studied first and third year chemistry students at an Australian university using the SPQ at five time points. No significant changes in surface or deep approaches over time were found. However, there was a positive correlation between grade point average (GPA) and the deep approach score, and a significant negative correlation between GPA and surface approach score, and the age of students correlated positively with academic performance.

In contrast, Vermetten, Vermunt and Lodewijks (1999) used the ILS to study students in the Netherlands over two years and found that students developed more "meaning-directed learning styles" as they progressed through their course. Donche, Coertjens, and van Petegem (2010) studied learning strategies using the ILS questionnaire in Belgian university students (non-science) over more than two 
years of study. Paired analysis showed a trend towards more 'meaning-directed learning' and less use of a surface approach over the period of study (Donche et al., 2010).

\section{Context of longitudinal study}

In a previous study we reported that a cohort of first year health science students was initially more likely to take a surface approach to learning, but a statistically significant move to a deeper learning approach was developed over one year of study (Walker et al., 2010). Further, there was a significant positive correlation between the extent that students adopted a surface approach to learning and their final grade (Walker et al., 2010). At that time we hypothesised that workload pressure and parts of the assessment, by necessity, were rewarding a surface approach, preventing further development of a deeper approach to learning. We were therefore interested in following these students as they progressed through university. We focused on a cohort of students who undertook physiology and anatomy majors in their training towards a science degree to determine if the design of the curriculum in anatomy and physiology is promoting deep approaches to learning, particularly in more advanced years of study.

\section{Objectives of study}

The research objectives of the present study were to

\section{Identify third year undergraduate physiology and anatomy students' approaches to learning and studying;}

2. Compare students' approaches to learning and studying in their first and third years of undergraduate study; and

3. Correlate students' approaches to learning and studying and their performance on assessment.

\section{METHODS}

\section{Institutional setting}

The study occurred at the University of Otago, a research-intensive university in New Zealand. The university is the oldest in the country and recently obtained a QS rating of five stars plus (QS World University Rankings, 2018). The institution has a tradition of excellence in teaching (as well as research), with a strategic Teaching and Learning Plan (University of Otago, 2013). Alongside the Plan are both Guidelines For Teaching and Guidelines For Learning that include a focus on encouraging students to take a deep approach to learning. The Higher Education Development Centre offers many workshops and opportunities to encourage teachers to think about their teaching strategies, while the Student Learning Centre runs sessions for students to encourage deep approaches to learning.

\section{Course setting}

Students were undertaking a three-year undergraduate degree in sciences (or health sciences) that included anatomy and physiology courses. At the beginning of their first year this student cohort was encouraged to take a deep learning approach to their learning (e.g., pre-reading the textbook prior to each lecture, note-taking strategies such as focusing on concepts rather than rote-learning facts, making links between material in different sections of the course, revising material after each lecture and throughout the semester, forming study groups, and using the Student Learning Centre). This advice was given in the first lecture and reinforced in their first guided-learning module. At second year the anatomy and physiology courses extended concepts introduced at first year, and at third year courses were more focused on the research strengths of the lecturers. Some third year courses were textbook- 
based, while others relied solely on original research articles. Anatomy and physiology third year courses comprised both lectures and laboratories with internal assessment (40 to 50\%) based on laboratory reports, essays, worksheets, and individual and group research seminars (physiology), or research presentations, essays, and short answer assessments (anatomy). Lecturers provided minimal lecture material to the students that typically contained objectives, pre-reading, references, and essential figures, similar to the lecture material provided at first and second year.

Many third year courses contained introductory information related to the university's graduate outcomes indicating that a deep approach to learning was expected; however, explicit discussion of learning strategies was not included in second or third year courses. Students appreciated that by third year they needed to read original research articles and demonstrate a higher level of understanding of the topics, particularly in linking experimental research in the literature to concepts.

All the third year courses held a two-hour final examination (contributing 50 to $60 \%$ of the final grade) that was typically in the form of two to four short or long essay-type questions. The questions suggested a deeper approach was expected of the students, asking them to 'Compare and contrast...,' 'Design an experiment...,' 'Explain the mechanism...,' or 'Support your answer using experimental evidence.'

\section{Data collection}

The students' approaches to learning and studying were obtained using the ASSIST questionnaire, which has three main sections: approaches to studying ( 52 items), conceptions of learning (6 items), and preferences for learning environment ( 8 items) (Tait et al., 1998). Each item consisted of a 5-point Likert scale, to which students had to respond. The 'approaches to studying' part of the questionnaire comprises a number of subscales, which are designed to measure the extent to which students take a deep, surface, or strategic approach to study. The strategic approach to studying is part of an 'achieving orientation' in which students are aware of study requirements and making sure they achieve these (Entwistle \& McCune 2004).

The ASSIST questionnaire was administered to first year (in 2007) and third year (in 2009) undergraduate anatomy and physiology students either in class or online ( $11 \%$ of the students used the online survey for the third survey only). Of the first year group 47 (25\%) students completed the ASSIST survey fully at all three time points: at the beginning and end of their first year of study, and again near the end of their third year of study. These students therefore formed a cohort for longitudinal analysis. In 2007, students in the cohort were aged 18 to 21 (mean \pm SD: $19.1 \pm 0.7$ years old). There were ten 18 year olds, 2819 year olds, six 20 year olds, and three 21 year olds. In 2009, students in the cohort were aged 20 to 23 (mean \pm SD: $21.1 \pm 0.7$ years old).

Ethical approval was obtained from the University of Otago Human Ethics Committee, and participants received an information sheet at the time of completing the questionnaire.

\section{Data analysis}

Data were analysed using IBM SPSS Ver 20. Overall significance level was set to $P<0.05$. To analyse the predominant approach to study, the main ASSIST scale scores were normalised. This is because the 'strategic' approach was made up of five subscales, whereas the 'deep' and 'surface' approaches comprised four subscales. For ease of comparison, a maximum score of 20 was obtained by dividing each main scale by the number of contributing subscales for each participant. A series of oneway ANOVAs with Bonferonni posthoc analysis were used to test for differences in approaches between students in the beginning and end of their first year of study in 2007, and those enrolled in third year 
anatomy or physiology papers in 2009. Acknowledging that each main scale was made up of a number of subscales, to reduce the probability of a Type I error, the significance level for the ANOVAs for the main scales was divided by the number of subscales within, thus the level of significance for the surface approach was $P<0.0125(P=(0.05 / 4))$. Where there was a violation of the homogeneity assumption, Kruskal-Wallis tests were used. To determine if students' approaches to learning and their performance in assessment were related, Pearson correlations were performed.

\section{RESULTS}

In this section we first compare approaches to learning in students' first and third years of study, and then we correlate students' approaches to learning with assessment.

\section{Comparison of approaches to learning in students' first and third years}

The extent to which students adopted deep, strategic, and surface learning approaches at the beginning and end of their first year of study, and at the end of their three-year undergraduate degree are shown in Table 1.

Table 1. Comparison of a cohort of 47 students' approaches to learning at the start and end of their first year of study and near the end of their third year of study

\begin{tabular}{|c|c|c|c|c|c|}
\hline Scales and subscales & $\begin{array}{l}\text { Start of first year } \\
\text { of student } \\
\text { Mean (SD) }\end{array}$ & $\begin{array}{l}\text { End of first year } \\
\text { of study } \\
\text { Mean (SD) }\end{array}$ & $\begin{array}{l}\text { End of third year } \\
\text { of study } \\
\text { Mean (SD) }\end{array}$ & Test statistic & $\begin{array}{l}\text { Significance level of } \\
\text { 3rd year vs start of } \\
\text { 1st year/ } 3 \text { rd year } \\
\text { vs end of 1st year }\end{array}$ \\
\hline Deep & $37.28(7.10)$ & $38.87(7.43)$ & $59.96(8.25)$ & $\mathrm{F}=130.1$ & $0.0001 / 0.0001$ \\
\hline Seeking meaning & $9.70(2.31)$ & $9.77(2.47)$ & $14.81(2.67)$ & $\mathrm{F}=65.2$ & $0.001 / 0.001$ \\
\hline Relating ideas & $9.68(2.54)$ & $10.23(2.19)$ & $14.45(2.73)$ & $\mathrm{F}=51.2$ & $0.001 / 0.001$ \\
\hline Use of Evidence & $9.13(2.18)$ & $10.06(2.73)$ & $14.68(2.64)$ & $F=65.0$ & $0.001 / 0.001$ \\
\hline Interest in ideas & $8.77(2.42)$ & $8.81(2.68)$ & $16.02(2.56)$ & $F=125.9$ & $0.001 / 0.001$ \\
\hline $\begin{array}{l}\text { Normalised mean deep } \\
\text { score }\end{array}$ & $9.32(1.77)$ & $9.72(1.86)$ & $14.99(2.06)$ & & \\
\hline Surface & $50.09(7.48)$ & $47.62(8.16)$ & $45.87(8.93)$ & $F=3.05$ & $\mathrm{NS} / \mathrm{NS}$ \\
\hline Unrelated memorising & $12.30(2.32)$ & $12.02(2.59)$ & $10.94(2.44)$ & $F=4.05$ & $0.05 / \mathrm{NS}$ \\
\hline Lack of purpose & $16.41(2.22)$ & $15.57(3.23)$ & $8.66(3.64)$ & ${ }^{\mathrm{a}} \mathrm{K}=69.2$ & $0.001 / 0.001$ \\
\hline Syllabus-bound & $10.87(2.57)$ & $9.89(2.64)$ & $13.04(2.75)$ & $F=17.3$ & $0.001 / 0.001$ \\
\hline Fear of failure & $10.45(3.08)$ & $10.13(3.43)$ & $13.23(3.76)$ & $F=11.6$ & $0.001 / 0.001$ \\
\hline $\begin{array}{l}\text { Normalised mean } \\
\text { surface score }\end{array}$ & $12.52(1.79)$ & $11.98(2.09)$ & $11.39(2.14)$ & & \\
\hline Strategic & $47.09(8.30)$ & $50.57(9.31)$ & $73.96(12.63)$ & ${ }^{\mathrm{a}} \mathrm{K}=74.0$ & $0.0001 / 0.0001$ \\
\hline Organised studying & $10.74(2.58)$ & $11.26(2.40)$ & $13.45(3.32)$ & ${ }^{\mathrm{a}} \mathrm{K}=21.0$ & $0.001 / 0.001$ \\
\hline Time management & $9.43(2.66)$ & $10.68(3.14)$ & $13.89(3.78)$ & ${ }^{\mathrm{a}} \mathrm{K}=35.6$ & $0.001 / 0.001$ \\
\hline $\begin{array}{l}\text { Alertness to assessment } \\
\text { demands }\end{array}$ & $10.23(2.07)$ & $10.11(2.24)$ & $15.04(3.13)$ & $\mathrm{F}=58.4$ & $0.001 / 0.001$ \\
\hline Moritoring effectiveness & $8.34(1.87)$ & $8.60(2.53)$ & $16.36(2.51)$ & ${ }^{\mathrm{a}} \mathrm{K}=91.9$ & $0.001 / 0.001$ \\
\hline $\begin{array}{l}\text { Achievement } \\
\text { motivation }\end{array}$ & $8.34(2.22)$ & $9.64(2.25)$ & $15.21(2.96)$ & ${ }^{\mathrm{a}} \mathrm{K}=76.2$ & $0.001 / 0.001$ \\
\hline $\begin{array}{l}\text { Normalised mean } \\
\text { strategic score }\end{array}$ & $9.30(1.71)$ & $10.10(1.92)$ & 14.82 & & \\
\hline
\end{tabular}

70 McDonald, F., Reynolds, J., Bixley, A., \& Spronken-Smith, R. (2017). Changes in approaches to learning over three years of University undergraduate study. Teaching \& Learning Inquiry, 5(2). http://dx.doi.org/10.20343/teachlearninqu.5.2.6 


\begin{tabular}{lccccc}
\hline $\begin{array}{l}\text { Learning environment } \\
\text { preference }\end{array}$ & & & & & \\
$\begin{array}{l}\text { Deep (encouraging } \\
\text { understanding) }\end{array}$ & $9.74(2.93)$ & $11.51(2.93)$ & $14.13(3.29)$ & $\mathrm{F}=24.5$ & $0.001 / 0.001$ \\
$\begin{array}{l}\text { Surface (transmitting } \\
\text { information) }\end{array}$ & $7.00(2.99)$ & $6.32(2.33)$ & $16.85(2.69)$ & $\mathrm{F}=272.6$ & $0.001 / 0.001$ \\
\hline $\begin{array}{l}\text { Conception of learning } \\
\begin{array}{l}\text { Deep (personal } \\
\text { understanding) }\end{array}\end{array}$ & $6.00(2.07)$ & $5.98(1.88)$ & $12.53(2.09)$ & $\mathrm{F}=164.4$ & $0.001 / 0.001$ \\
$\begin{array}{l}\text { Surface (knowledge } \\
\text { reproduction) }\end{array}$ & $4.87(1.69)$ & $5.32(1.83)$ & $12.66(1.86)$ & $\mathrm{F}=277.5$ & $0.001 / 0.001$ \\
\hline
\end{tabular}

${ }^{a}$ Kruskal-Wallis test due to violation of homogeneity assumption (Levene's test $P<0.05$ )

In their third year, the predominant approaches to studying taken by the students were the deep and strategic approaches, followed by the surface approach. There was a significant change in students' approaches to learning over their three years of undergraduate study. A comparison of mean scores at first and third year showed a steep and significant increase in strategic and deep approaches, and the surface approach scores trending downwards over the three years of study. To compare the extent to which these scores altered over time, the normalised mean scores of the cohort are plotted against time for the two timepoints in their first year of study and one timepoint in their third year (discussed below) (Fig.1).

Figure 1. Normalised ASSIST scores.

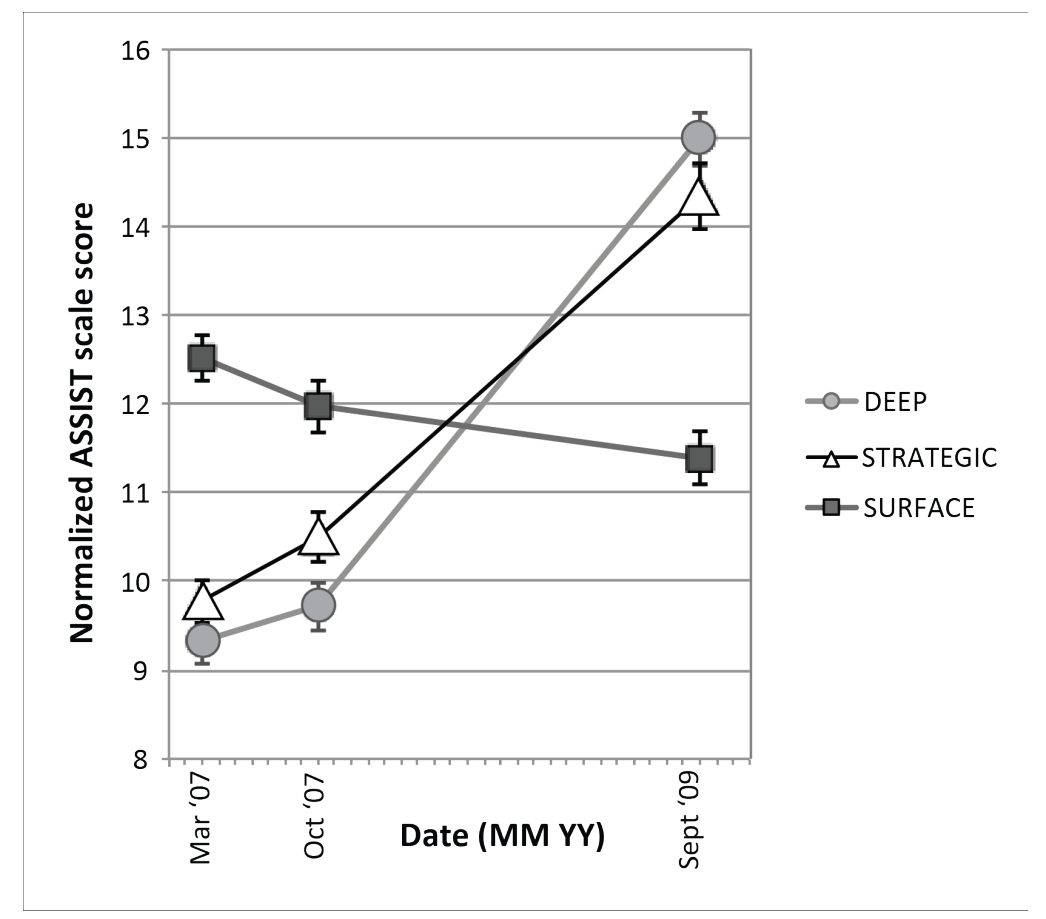

Normalised ASSIST scores in each scale for all students who completed all sections of the ASSIST at the beginning (Mar '07) and end (Oct '07) of their first year of study and in their third year (Sept '09). ( $n=47)$, $\mathrm{MM}=$ month, $\mathrm{YY}=\mathrm{year}$. 


\section{Subscale analysis}

Deep approach: There was a significant increase in the extent that third year students adopted deep approaches to learning, and significant increases across all subscales, with the third year students' interest in ideas increasing the most (Table 1). There were also increases in students' seeking meaning in what they were studying, relating ideas, and using evidence to support their study.

Strategic approach: There were increases in students' use of strategic approaches, with significant increases across most subscales. The two subscales showing the highest gains were the ability of students to monitor the effectiveness of their study, and their motivation for achievement.

Surface approach: By comparison to the deep and strategic scores there was less shift in the surface approach scores across the three years. We previously reported that there was a significant decrease in surface score for a larger cohort of first year students during their academic year (Walker et al., 2010), and this trend appears to continue to a minor extent into the students' third year, but is not a statistically significant decrease. Closer analysis shows that the subscales moved in different directions. The third year students' lack of purpose decreased significantly, while there was a significant increase in the students' being syllabus-bound, and in their fear of failure. In contrast, third year students' reported use of unrelated memorising was not significantly different to that at the end of their first year of study.

There was an interesting shift in the learning environment preference reported by the third year students. Environments that promoted surface learning approaches, such as lectures, were preferred to a greater extent compared to the first year cohort. However teaching environments encouraging deep approaches to learning were also preferred to a greater extent compared to the cohort at first year (Table 1). There was also a significant increase in the third year students' conception of both surface and deep approaches to learning.

A correlation of approaches to learning scores at first and third year for individual students from the cohort was performed (Fig. 2). Non-normalised scores were used for this analysis, similar to our previous analyses (Walker et al., 2010). Use of deep and strategic approaches to learning remained high for those students with relatively high use of deep and strategic approaches at first year, but students who reported low use of these learning approaches at first year reported greatly increased use of deep and strategic learning strategies at the end of third year (Fig 2A, B). For example, some students at first year with scores at the higher end of the range of deep scores $(\sim 50)$ showed a small or no increase in deep scores at third year. Other students starting at a typical low deep score (30) in first year moved up to scores of 65-75 in third year. In contrast, inspection of the shift in surface learning scores (Fig. 2C) shows that the use of surface approaches decreased over the three years for the majority of students, but this was offset by a small increase in the use of surface approaches by those with lower use of surface approaches in first year. For example, some students at first year with typical scores at the low end of the surface range $(\sim 40)$ moved to scores of around 50 to 60 at the end of third year.

\section{Correlation of students' approaches to learning with assessment}

The extent to which students took both strategic and deep approaches to learning in their third year was positively correlated with their performance on assessment. These showed Pearson correlation coefficients of $\mathrm{r}=0.56(P<0.01)$ for strategic, and $\mathrm{r}=0.27(P<0.05)$ for deep. The correlation between student performance and adopting more surface approaches to learning was not significant $(\mathrm{r}=-0.18$, NS). These contrasted with the same students' correlations between learning approaches and their final exam marks at the end of their first year of study. For the surface approach, a higher grade in their first year exam was correlated with a higher surface approach $(\mathrm{r}=0.30, \mathrm{P}<0.05)$, whereas the reverse was apparent with their deep $(\mathrm{r}=-0.31, \mathrm{P}<0.05)$ and strategic $(\mathrm{r}=-0.30, \mathrm{P}<0.05)$ approaches. Together, 
this suggests that a surface learning approach was better suited to achieving success in the first year exam, whereas third year exam success was better achieved by students with high scores for strategic and deep approaches.

Figure 2. Correlation of individual students' learning approach scores at third year with the end of first year.

A

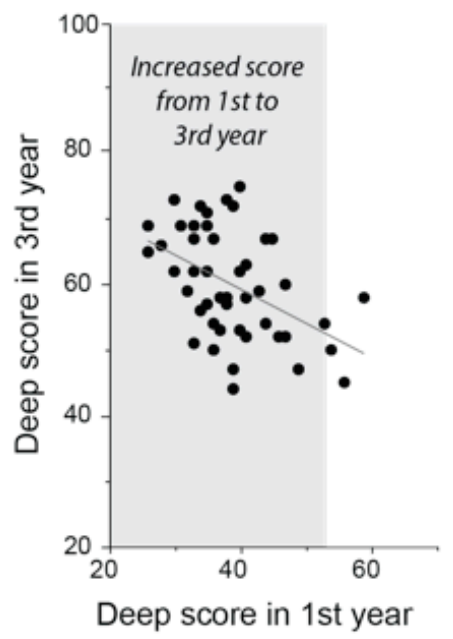

B

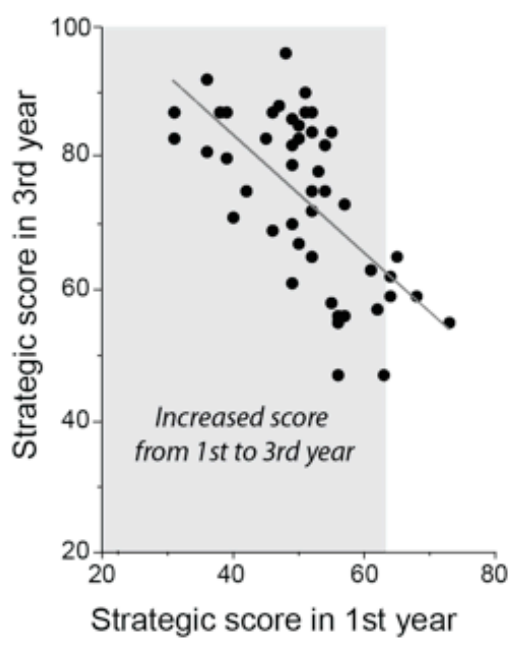

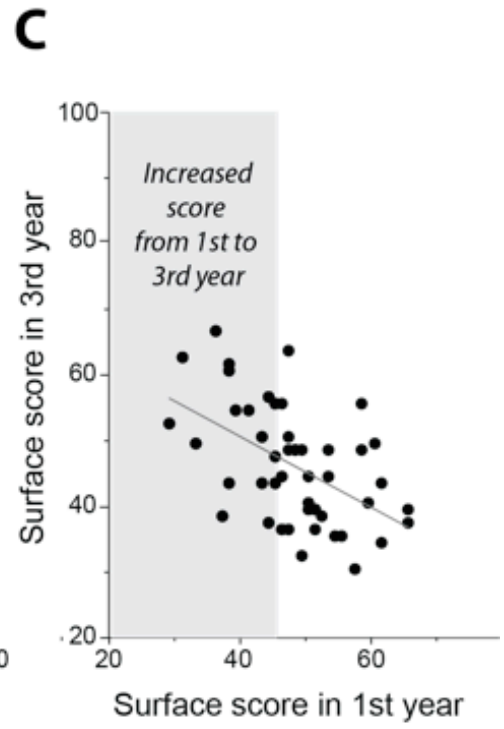

The shaded area includes the points on the regression curve where scores in first year were increased by third year.
A) Regression equation for deep scores: $\mathrm{y}=80.26-0.522 x . \mathrm{R}^{2}=0.22(P<0.001)$.
B) Regression equation for strategic scores: $\mathrm{y}=118.8-0.893 \mathrm{x} . \mathrm{R}^{2}=0.44(P<0.0001)$.
C) Regression equation for surface scores: $y=71.6-0.542 x . R^{2}=0.32(P<0.001)$.

\section{DISCUSSION}

\section{Changes in approaches to learning over three years}

Over the three years of their undergraduate science degree there was a change in students' approaches to learning from predominantly surface approaches to both deep and strategic approaches being used to a greater extent. A number of contextual factors are likely to have promoted this change at third year:

1. The curriculum lays the foundations at first year, then builds on those concepts at second and third year, allowing the students to develop a deeper understanding of the material. Courses, particularly at third year, focus on practical experience with experimental design and analysis, and students are expected to understand and report on original scientific papers, thus encouraging them to relate information, be interested in ideas, and use evidence-based learning.

2. Class sizes are smaller compared to first year (which was about 2000 students), allowing for better interaction with lecturers and more personalised feedback.

3. To attain good grades in the major assessment (final examination), understanding of complex biological processes was required.

4. Student maturation and life experience are likely to be factors in the increased scores of deep and strategic learning approaches. Other groups have reported that older students tend to 
display higher deep approach and lower surface approach scores, and tend to perform well in assessment (e.g., Biggs, Kember \& Leung, 2001; Zeegers, 2001). Since all of our students were in the same age range (20-23 years) at completion, this suggests that a time effect experience of the tertiary environment rather than an age effect is involved in the significant shift to deeper and strategic approaches to learning.

Thus the changes observed are likely a response to a combination of a more engaging learning environment, teaching and learning activities and assessments that require deep and strategic approaches to gain high grades, and also reflect maturation of students' learning strategies that have developed by the end of their third year of study. The time taken to see the shift in learning approach is echoed in work by Bolhuis (2003) who stated:

Changing to a new learning strategy may be conceived of as a conceptual change. The 'old' strategy keeps competing with the new strategy for some time. Even when students have learned better learning strategies, they may not always choose to use them. Only after a long time of practice and positive results, does the new strategy take over (p. 332)

Our results also show that third year students retained some use of surface approaches to learning. We suspect that in anatomy and physiology, students will continue to memorise material throughout their study, but we think this is likely a meaningful, deep memorising as opposed to meaningless, rote memorising. Entwistle and Ramsden (1983) have noted that "A deep approach in science depends more on operation learning, on relating evidence and conclusion, and on the appropriate use of a certain amount of initial rote learning to master the terminology" (p.209). Such behavior may be responsible for the result that third year students have a high preference for a surface learning environment (but note the deep learning environment is also highly rated). Past studies (e.g., Lucas, 2001) have suggested that some inventories cannot adequately distinguish between the two types of memorising, so further exploration of this issue is warranted.

The variability in the extent of increase in deep and strategic approach scores observed in our correlations of third versus first year learning approach scores may also result from different student orientations to academia. Biggs (1999) proposed that some students arrive at university with a welldeveloped academic approach, primed to take a deep approach to learning, and, despite the teaching environment, will continue to operate at a higher cognitive level. Similarly, Wilson and Fowler (2005) reported that students already taking a deep approach do not shift in their approach to deep learning in response to a change in learning environment. However, other students begin study using a surface approach to learning, particularly if the teaching and assessment regime encourage this approach (Biggs, 1999). For the latter students, a more active learning environment coupled with an appropriate assessment regime can lead to a much greater increase in the use of higher level approaches to learning, compared to the former type of student who started with a deeper approach.

\section{Correlation of learning approaches with performance on assessment}

Our previous study reported that first year student performance in their final exam was negatively correlated with a deep approach but positively correlated with surface and strategic approaches to learning (Walker et al., 2010). We suggested that as students advanced in their degrees there would be a shift to more use of deep approaches to learning because the assessments would change to test deeper approaches. Assessment is an important contextual driver of learning approach (Byrne et 
al., 2002; Diseth 2007; Diseth \& Martinsen 2003; Diseth, Pallesen, Hovland, \& Larsen, 2006; Ramsden, 2003; Reid et al. 2007; Scouller, 1998; Walker et al., 2010); therefore curriculum design that includes assessment testing a deep approach to learning should encourage students into a deep approach as they will be rewarded with higher grades (Gordon \& Debus, 2002; Wilson \& Fowler, 2005). The third year internal assessments in anatomy and physiology included student presentations on original research articles, integrative essays, laboratory reports and research proposals, and a final examination comprised of essays that all required deep approaches such as relating theoretical and experimental aspects in a research field. Given this assessment regime it is not surprising that third year students who achieved higher grades used strategic and deep approaches to learning to a significantly greater extent, with positive correlations between strategic and deep learning approach and performance on assessment. Performance at third year was not significantly correlated with surface learning approaches; however, at first year, assessment performance of these same students was significantly correlated with surface learning approaches.

Significant positive correlations between a deep approach to learning and performance in assessment have been reported previously (e.g., Diseth, 2007; Zeegers, 2001), although other studies have found no significance, including our own study of a larger cohort at first year (Walker et al., 2010). In the latter, assessment at first year was not entirely focused on testing concepts, and competition for entry into health professional courses (which have their main entry at the end of first year) probably promoted rote learning. Moreover, by necessity a large amount of new vocabulary needed to be assimilated by the students-a factor that also likely promoted rote learning. By comparison, in their third year of anatomy or physiology study, students are building on concepts introduced at first and second year, and the assessment regime of in-depth laboratory reports and final examinations consisting of essays required critical analysis and understanding of original research articles. Therefore our results are in accordance with (Entwistle, 2000)

... assessment which encourages students to think for themselves-such as essay questions, applications to new contexts, and problem-based questions-shifts students in a class towards a deep approach. In contrast, procedures perceived by students as requiring no more than the accurate reproduction of information lead to a predominance of surface approaches. (p. 7)

\section{Implications for course design}

Based on our analysis we suggest the following course design principles to encourage deeper learning approaches:

1. Alignment of course outcomes with taught material and with assessment mode (i.e. ensuring that appropriate tasks are set to both learn and assess specific outcomes);

2. Use of transformative learning experiences (see Spronken-Smith, Buissink-Smith, Bond, \& Grigg, 2015), such as the opportunity to develop practical skills;

3. Offering opportunities for discussion of lecture and laboratory material with peers and lecturers;

4. Careful design of assessment to ensure this encourages a deeper approach to learning;

5. Consideration of student workload to include optimal timing between assessments in the course and other courses students are likely to be taking;

6. Clear avenues for ongoing support to teaching staff in adhering to these design and delivery principles, through regular teaching workshops. 


\section{Study limitations}

A variety of contextual factors may have influenced this study. For example, the study cohort received explicit encouragement to take a deep approach to learning in their first year of study (Walker et al., 2010). However it is expected that in addition to these explicit instructions at first year, maturation of student learning is occurring over their course of study due to contextual factors such as teaching and learning environments, the type of and experience with assessments, feedback on assessments, and their interactions with different teachers. Limitations introduced by the reliance on the single mode of selfreporting survey include relying on student honesty in reporting their approaches to learning and the lack of qualitative data to expand on analysis of contextual factors.

Our sample size is smaller than some other longitudinal studies in this area (Donche et al., 2010; Vermetten et al., 1999), and although repeating a similar survey with more students would be advantageous, the logistics of ensuring students complete surveys at multiple timepoints is difficult as first year health science students at our institution move into a variety of programs that would then expose the students to different learning environments, potentially biasing the data.

We considered whether the cohort was biased due to failure of students taking a predominantly surface approach to progress to a third year of study. However the student grades in this cohort varied from $\mathrm{C}$ to $\mathrm{A}+$, indicating that a range of strong and weaker students completed the survey. Also, our paired analysis of students in the cohort reporting differences in learning behavior in third year compared to first year suggests a majority of the cohort who study anatomy and physiology have changed their learning strategies.

\section{CONCLUSIONS}

In this investigation we carried out a longitudinal study to compare the learning approaches taken by the same cohort of students in their first and third year of study. At the end of their third year of study students had developed deeper and more strategic learning approaches compared to their first year of study, and their performance in course assessments correlated positively with the use of deep and strategic learning approaches.

Avenues for future research should explore in more detail our findings that the third year students retained surface approaches to learning, including development of a method to separate meaningless (rote) memorising and meaningful (deep) memorising. In addition, they should explore the proposition that students arrive at university with different levels of preparedness to adopting higher level cognitive approaches to learning, which may affect their progression to using deep approaches to a greater extent.

Our study adds new knowledge to the literature affirming that as students progress through a three year undergraduate science degree their learning approaches change, and this reflects changes in teaching environments, expectations, and the assessment regime.

\section{ACKNOWLEDGEMENTS}

We thank the students enrolled in 300-level anatomy and physiology courses in 2009 who undertook the ASSIST survey, and Mr. Matthew Bixley for helpful comments on statistical analysis. This work was supported by an Ako Aotearoa National Tertiary Teaching Excellence Award to the second author.

Fiona McDonald is an Associate Professor of Physiology at the University of Otago, New Zealand. Her research interests include regulation of ion channels in epithelia and endothelia to control blood pressure. 
John Reynolds is a Professor of Neuroscience and the Director of the Health Sciences First Year Programme at University of Otago, New Zealand. His research areas are learning and reward mechanisms in the brain, stroke and brain plasticity and Parkinson's disease.

Ann Bixley was the Administrative Assistant for two of the First Year Health Science papers at the University of Otago, New Zealand. She holds an MSc in Ecology and PGDip Teaching (Secondary). Her research interests include control of New Zealand pastural pests by the introduced biological control agent Microctonus aethiopoides.

Rachel Spronken-Smith is a Professor of Higher Education and Geography, and Dean of the Graduate Research School at the University of Otago, New Zealand. Her research interests in Higher Education include curriculum change, undergraduate research and inquiry, graduate outcomes and doctoral education.

\section{NOTES}

1. Entwistle drew on the work of (Thomas \& Bain, 1984) and (Scoullar, 1998) to make this statement.

\section{REFERENCES}

Baeten, M., Kyndt, E., Struyven, K., \& Dochy, F. (2010). Using student-centred learning environments to stimulate deep approaches to learning: Factors encouraging or discouraging their effectiveness. Educational Research Review, 5, 243-260.

Biggs, J. (1987). The study process questionnaire manual: Student approaches to learning and studying. Hawthorn, AU: Australian Council for Educational Research.

Biggs, J. B. (1999). Teaching for quality learning at University. Buckingham, UK: Open University Press.

Biggs, J., Kember, D., \& Leung, D.Y.L. (2001). The revised two-factor study process Questionnaire: R-SPQ-2F. British Journal of Educational Psychology, 77, 133-149.

Bolhuis, S. (2003). Towards process-oriented teaching for self-directed lifelong learning: a multidimensional perspective. Learning and Instruction, 13, 327-347.

Byrne, M., Flood, B., \& Willis, P. (2002). The relationship between learning approaches and learning outcomes: a study of Irish accounting students. Accounting Education, 11, 27-42.

Dinsmore, D.L., Alexander, P.A., \& Loughlin, S.M. (2008). Focusing the conceptual lens on metacognition, selfregulation, and self-regulated learning. Educational Psychology Review, 20, 391-409.

Dinsmore, D.L., \& Alexander, P.A. (2012). A critical discussion of deep and surface processing: What it means, how it is measured, the role of context, and model specification. Educational Psychology Review, 24, $499-567$

Diseth, A., \& Martinsen, O. (2003). Approaches to learning, cognitive style, and motives as predictors of academic achievement. Educational Psychology, 23(2), 195-207.

Diseth, A., Pallesen, S., Hovland, A., \& Larsen, S. (2006). Course experience, approaches to learning and academic achievement. Education \& Training, 48(2/3), 156-169

Diseth, A. (2007). Students' evaluation of teaching, approaches to learning, and academic achievement. Scandinavian Journal of Educational Research, 51(2), 185-204.

Donche, V., Coertjens, L., \& Van Petegem, P. (2010). Learning pattern development throughout higher education: A longitudinal study. Learning and Individual Differences, 20, 256-259.

Entwistle, N., Hanley, M., \& Hounsell, D. (1979). Identifying distinctive approaches to studying. Higher Education, 8, 365-380.

Entwistle, N., \& Ramsden, P. (1983). Understanding student learning. London, UK: Croom Helm.

Entwistle, N. (1997). Reconstituting approaches to learning: A response to Webb. Higher Education, 33, $213-218$.

Entwistle, N. (2000). Promoting deep learning through teaching and assessment: Conceptual frameworks and educational contexts. Paper presented at The First Annual Conference Of The Teaching And Learning Research Programme. Leicester, UK. Abstract retrieved from http://www.etl.tla.ed.ac.uk/publications.html.

Entwistle, N., Tait, H., McCune, V. (2000). Patterns of response to an approaches to studying inventory across contrasting groups and contexts. European Journal of Psychology of Education, 15(1), 33-48.

Entwistle, N., \& McCune, V. (2004). The conceptual bases of study strategy inventories. 
Educational Psychology Review, 16(4), 325-345.

Entwistle, N. J., \& Peterson, E. R. (2004). Conceptions of learning and knowledge in higher education: Relationships with study behavior and influences of learning environments. International Journal of Educational Research, 41, 407-428.

Ertl, H., \& Wright, S. (2008). Reviewing the literature on the student learning experience in higher education. London Review of Education, 6(3), 195-210.

Gibbs, G. R. (1999). Learning how to learn using a virtual learning environment for philosophy. Journal of Computer Assisted Learning, 15, 221-231.

Gibbs, G., \& Coffey, M. (2004). The impact of training of university teachers on their teaching skills, their approach to teaching and the approach to learning of their students. Active Learning in Higher Education, 5(1), 87-100.

Gordon, C., \& Debus, R. (2002). Developing deep learning approaches and personal teaching efficacy within a preservice teacher education context. British Journal of Educational Psychology, 72, 483-511.

Gow, L., \& Kember, D. (1990). Does higher education promote independent learning? Higher Education, 19, 307322.

Greasley, A., \& Bennet, D. (2004). A virtual learning environment for operations management. International Journal of Operations \& Production Management, 24(10), 974-993.

Kane, R., Sandretto, S., Heath, C. (2002). Telling half the story: A critical review of research on the teaching beliefs and practices of university academics. Review of Educational Research, 72(2), 177-228.

Kember, D., \& Kwan, K-P. (2000). Lecturers' approaches to teaching and their relationship to conceptions of good teaching. Instructional Science, 28, 469-490.

Lucas, U. (2001). Deep and surface approaches to learning within introductory accounting: a phenomenographic study. Accounting Education, 10(2), 161-184.

Maguire, S., Evans, S. E., \& Dyas, L. (2001). Approaches to learning: A study of first-year geography undergraduates. Journal of Geography in Higher Education, 25(1), 95-107.

Marton, F., \& Saljo, R. (1976). On qualitative differences in learning: I. Outcome and process. British Journal of Educational Psychology, 46, 4-11.

Marton, F., Dall'Alba, G., \& Tse, L. K. (1993). The Paradox of the Chinese Learner. Melbourne, Australia: Educational Research and Development Unit, Royal Melbourne Institute of Technology.

Marton, F., \& Säljö, R. (1997). Approaches to learning. In F. Marton, D. Hounsell, \& N. Entwistle

(Eds.), The experience of learning. Implications for teaching and studying in higher education (2nd ed., pp. 3958). Edinburgh: Scottish Academic Press.

Pashler, H., McDaniel, M., Rohrer, D., Bjork. R. (2008). Learning styles: Concepts and evidence. Psychological Science in the Public Interest, 9, 106-119.

Pintrich, P.R. (1991). A conceptual framework for assessing motivation and self-regulated learning in college students. Educational Psychology Review, 16, 385-407.

Postareff, L., Lindblom-Yla"nne, S., Nevgi, A. (2007). The effect of pedagogical training on teaching in higher education. Teaching and Teacher Education, 23, 557-571.

Prosser, M., \& Trigwell, K. (1999). Understanding learning and teaching: The experience in higher education. Buckingham, UK: The Society for Research into Higher Education and Open University Press.

QS World University Rankings (2018). QS world university rankings. Retrieved from: http://www.topuniversities.com/university-rankings.

Ramsden, P. (2003). Learning to teach in higher education (2nd ed). London, UK: Routledge.

Reid, W. A., Duvall, E., \& Evans, P. (2007). Relationship between assessment results and approaches to learning and studying in year two medical students. Medical Education, 41, 754-762.

Samuelowicz, K., \& Bain, J. D. (1992). Conceptions of teaching held by academic teachers. Higher Education, 24, 93-111.

Schmeck, R. R., Ribich, F., \& Ramanaiah, N. (1977). Development of a self-report inventory for assessing individual differences in learning processes. Applied Psychological Measurement, 1, 413-431.

Schmeck, R. R., Geisler-Brenstein, E., \& Cercy, S.P. (1991). Self-concept and learning: the revised inventory of learning processes. Educational Psychology, 11, 343-362.

Scouller, K. (1998). The influence of assessment method on students' learning approaches: Multiple choice question examination versus assignment essay. Higher Education, 35, 453-452.

78 McDonald, F., Reynolds, J., Bixley, A., \& Spronken-Smith, R. (2017). Changes in approaches to learning over three years of University undergraduate study. Teaching \& Learning Inquiry, 5(2). http://dx.doi.org/10.20343/teachlearninqu.5.2.6 
Speth, C. A., Lee, D. J., \& Hain, P. M. (2006). Prioritizing improvements in internet instruction based on learning styles and strategies. Journal of Natural Resources \& Life Sciences Education, 35, 34-41.

Spronken-Smith, R.A., Buissink-Smith, N., Bond, C. \& Grigg, G. (2015). Graduates' orientations to higher education and their retrospective experiences of teaching and learning. Teaching \& Learning Inquiry, 3, 55-70.

Tait, H., Entwistle, N., \& McCune, V. (1998). ASSIST: A reconceptualisation of the Approaches to Studying Inventory. In C. Rust (Ed.), Improving student learning. Improving students as learners (pp. 262-271). Oxford, UK: The Oxford Centre for Staff and Learning Development. Survey tool retrieved from: http://www.etl.tla.ed.ac.uk/questionnaires/ASSIST.pdf

Thomas, P. R., \& Bain, J. D. (1984). Contextual dependence of learning approaches: The effects of assessments. Human Learning, 3, 227-240.

Trigwell, K., Prosser, M., \& Waterhouse, F. (1999). Relations between teachers' approaches to teaching and students' approaches to learning. Higher Education, 37, 57-70.

University of Otago (2013). University of Otago Teaching and Learning Plan (2013-20). Retrieved from http://www.otago.ac.nz/staff/otago027123.pdf.

Vermetten, Y. J., Vermunt, J. D., \& Lodewijks, H. G. (1999). A longitudinal perspective on learning strategies in higher education - Different view-points towards development. British Journal of Educational Psychology, 69, 221-242.

Vermut, J. D. (1996). Metacognitive, cognitive and affective aspects of learning styles and strategies: A phenomenographic analysis. Higher Education, 31, 25-50.

Walker, R., Spronken-Smith, R., Bond, C., McDonald, F., Reynolds, J., \& Martin, A. (2010). The impact of curriculum change on health science first year students' approaches to learning. Instructional Science, 38(6), 707722.

Watkins, D. \& Hattie, J. (1985). A longitudinal study of the approaches to learning of Australian tertiary students. Human Learning, 4, 127-141.

Webster, R. (2002). Learning styles and design: The use of ASSIST for reflection and assessment. Proceedings of the 2002 Annual International Conference of the Higher Education Research and Development Society of Australasia (HERDSA), Perth, Australia. http://www.herdsa.org.au/index.php?page_id=175.

Weinstein, C. E. (1982). Training students to use elaboration learning strategies. Contemporary Educational Psychology, 7, 301-311.

Wilson, K., \& Fowler, J. (2005). Assessing the impact of learning environments on students' approaches to learning: Comparing conventional and action learning designs. Assessment and Evaluation in Higher Education, 30(1), 87-101.

Zeegers, P. (2001). Approaches to learning in science: A longitudinal study. British Journal of Educational Psychology, 71, 115-132.

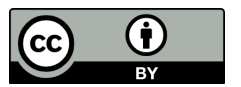

Copyright for the content of articles published in Teaching \& Learning Inquiry resides with the authors, and copyright for the publication layout resides with the journal. These copyright holders have agreed that this article should be available on open access under a Creative Commons Attribution License 4.0 International (https://creativecommons.org/licenses/by/4.0). The only constraint on reproduction and distribution, and the only role for copyright in this domain, should be to give authors control over the integrity of their work and the right to be properly acknowledged and cited, and to cite Teaching \& Learning Inquiry as the original place of publication. Readers are free to share these materials - as long as appropriate credit is given, a link to the license is provided, and any changes are indicated. 